\title{
DESAIN DAKWAH SAYID IDRUS DI SULAWESI TENGAH
}

\author{
Norma Dg. Siame \\ Dosen Pada Jurusan Aqidah Filsafat IAIN Palu \\ Samsinas Samsinas \\ email: samsinas29@yahoo.co.id
}

Dosen Tetap Pada Jurusan Pengembangan Masyarakat Islam IAIN Palu

\section{Abstract:}

Sayyid Idrus is a preacher in modera era in 1929. This era is also known as a period in which an idea of Islamic renewal had flourished in the Muslim world. It is not surprising that an idea of Islamic renewal has also influenced Sayyid Idrus's thought and preaching design, which in turn has a significant impact on the people of Palu in particular, and Central Sulawesi in general. This paper used historical analysis with science of da'wah approach. There are several da'wah steps taken by Sayyid Idrus: (1) he began his preaching through meeting with society's leading figures in Palu. This step opens the way for him to obtain some facilities for his preaching. As a result, his preaching which is traditionally carried out from house to house leads to the establishment of Islamic schools; (2) From simple Islamic schools, he could build representative building to accommodate a lot of students and also build orphanage. These schools have significantly increased until today; (3) He implemented some systems either in student admission as an object of da'wah (mad'u), system of preaching, or content of preaching; (4) He carried out da'wah through modernizing education; (5) He conducted educational training for students and cadre formation at the national or international levels.

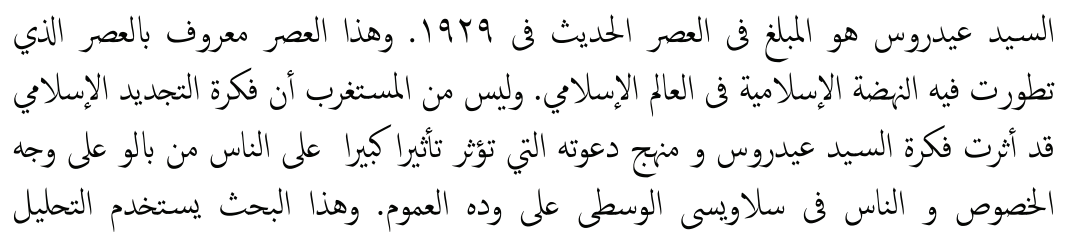


Norma Dg. Siame \& Samsinas Samsinas, Desain Dakwah Sayid Idrus....

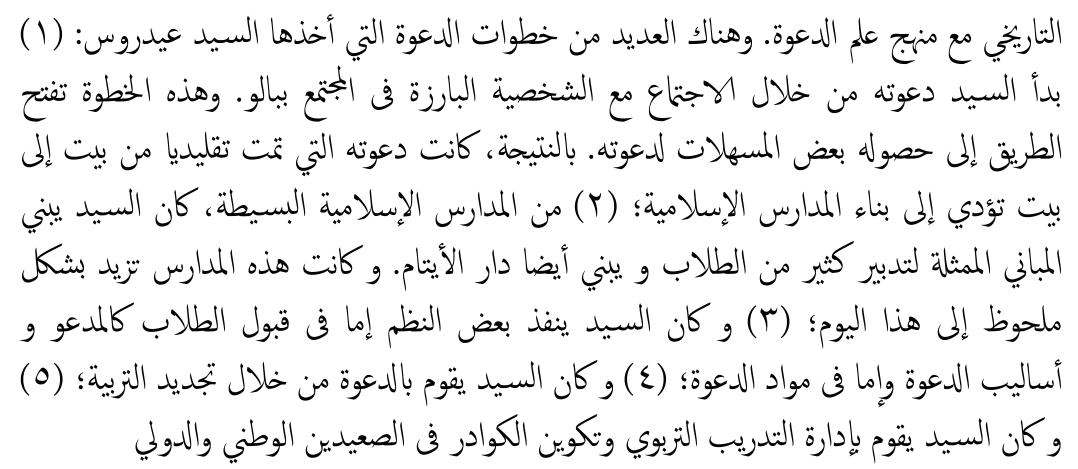

Kata Kunci: desain, dakwah, Sayid Idrus

\section{Pendahuluan}

Dakwah islamiah merupakan keniscayaan para ulama masa awal dalam berbagai kesempatan dan kiprahnya. Pada tahun 1930 muncul seorang ulama dari Hadramaut, Yaman Selatan bernama Sayid Idrus bin Salim Aldjufri. Ia disebut sebagai da'i yang telah melakukan banyak perubahan dan pembaharuan dibidang keagamaan bagi masyarakat di Sulawesi Tengah.

Dalam dakwahnya, Sayid Idrus melakukan pendekatanpendekatan, beradaptasi, dan bergaul serta berpartisipasi dengan semua pihak, dari berbagai strata sosial dan golongan, tidak membedakan antara golongan satu dengan golongan lainnya semuanya diperlakukan sama dengan penuh rasa hormat dan tawadhu (merendahkan diri), masyarakat merasa kagum dan bersimpati serta menaruh hormat menyaksikan sikap seorang ulama yang rendah hati, mudah bergaul, sehingga misi yang dibawa memungkinkan masyarakat terdorong untuk menerimanya. Hal ini juga karena memang sebahagian masyarakat menginginkan adanya suatu perubahan dalam keberagamaan, disebabkan tidak puas hanya sekedar masuk Islam tetapi tidak mengerti 


\section{$\Delta$ L-nish $\exists \bar{d} / H$, Vol. 11 No. 1, Januari-Juni 2015: 21-46}

atau mengetahui seluk beluk hukum Islam. Maka bersamaan dengan munculnya Sayid Idrus masyarakat secara sukarela menerima sebagai pemimpin agama Islam dan berhasil melakukan perubahan pembaharuan dibidang sosial keagamaan tanpa mengalami hambatan dan tantangan yang berati.

Dengan demikian, Sayid Idrus mampu melakukan terobosan dan perubahan-perubahan dalam masyarakat secara signifikan. Sehingga dalam kurun waktu 39 tahun mampu menyebarluaskan dakwahnya diberbagai daerah di Sulawesi Tengah dan sekitarnya dengan membangun sekolah madrasah sebanyak 420 buah. Madrasah-madrasah ini sebahagian berada di Palu dan sekitarnya, serta Sulawesi Tengah pada umumnya. Sebahagian lagi Sulawesi Utara, Sulawesi Tenggara, Sulawesi Selatan, Irian Jaya, Maluku dan Kalimantan Timur. ${ }^{1}$ Itulah sebabnya masyarakat Islam Sulawesi Tengah memberi penghargaan kepada Sayid Idrus dengan menjadikan salah satu alasan kenapa Sayid Idrus digunakan sebagai nama jalan dan bandar udara di Kota Palu.

Ketokohan Sayid Idrus memang cukup familiar dikalangan masyarakat Kota Palu sehingga ajaran-ajaran beliau benar-benar mengakar di seluruh kalngan di Kota palu terutama warga Alkhairaat, namun demikian belum banyak peneliti yang meneliti tentang desain dakwahnya. Bagaimana desain dakwah Sayid Idrus selama menjalankan kegiatan dakwah di Kota palu Sulawesi Tengah ? Persoalan inilah yang akan menjadi bahan kajian dalam artikel ini.

${ }^{1}$ Mahmud Samsu As., Ulama Pembawa Islam di Indonesia dan Sekitarnya (Jakarta: Lentera, 1996), h. 131. 
Norma Dg. Siame \& Samsinas Samsinas, Desain Dakwah Sayid Idrus....

\section{Metode Penelitian}

Penelitian ini berlokasi di Kota Palu, dengan obyek kajian tokoh yakni Design Dakwah Sayid Idrus di Kota Palu. Kota Palu merupakan Kota dimana bekas dakwah Sayid Idrus masih kongkrit sehingga dapat dijadikan bukti dan bahan penelitian Seperti pesantren atau madrasahmadrasah Alkhairaat, masjid dan murid-murid Sayid yang masih hidup. Kota Palu juga merupakan tempat dimana Kantor Pusat atau Pimpinan Pusat Alkhairaat berada. Sehingga data untuk tingkat lokal maupun nasional dapat diperoleh di sini.

Penelitian ini menggunakan jenis penelitian kualitatif deskriptif dengan menggunakan analisis sejarah dengan pendekatan Ilmu Dakwah. Sedangkan teknik pengumpulan data menggunakan teknik wawancara, observasi, studi naskah atau dokumentasi. Sebagai sumber data primer, penulis memilih tokoh-tokoh kunci yang pernah menjadi murid Sayid Idrus semasa hidupnya, para pengurus Alkhairaat serta sebahagian lagi data diambil dari keluarga atau keturunan dari Sayid Idrus yang masih hidup. Diluar itu adalah sumber dari hasil pengamatan langsung terhadap kegiatan-kegiatan kealkhairaatan dan sistem pendidikan di madrasah, melihat langsung sarana atau bangunan-bangunan fisik dan benda-benda peninggalan Sayid dilapangan yang digabungkan dengan analisis sumber dari naskah karya Sayid idrus dan murid-muridnya dalam bentuk buku, foto dan dokumen lainnya.

\section{Pembahasan}

A. Biografi Sayid Idrus

Sayid Idrus, yang oleh masyarakat Palu lebih populer menyebut Guru Tua, memiliki nama lengkap Sayid Idrus bin Salim Aldjufri lahir di 
Taris, letaknya tidak jauh dari Kota Saiwon, ibu kota Propinsi Hadramaut, Yaman Selatan pada hari Senin 15 Sya'ban 1309 H / 16 Maret 1889 M. ${ }^{2}$

Ayahandanya bernama Sayid Salim Aldjufri bin Alawy, seorang mufti (Badan Penasihat Pemerintahan) di Hadramaut yang mempunyai silsilah dari keluarga besar Ba'lawy, keturunan ulama besar dan masih mempunyai pertalian darah dengan Ali bin Abi Thalib, khalifah ke empat dari khulafaur-rasyidin. Adapun silsilah Sayid Idrus adalah sebagai berikut:

1. Ali bin Abi Thalib

2. Hasan

3. Ali Zainul Abidin

4. Muhammad Baqir

5. Djafar Shadiq

6. Ali Aridh

7. Muhammad Naqib

8. Isa Naqib

9. Ahmad Muhajir

10. Abdullah

11. Muhammad Faqih Muqaddam

12. Ali

13. Muhammad

14. Ali

15. Alwy

16. Muhammad

17. Alwy

${ }^{2}$ Noor Sulaeman PL, Biografi S.Idrus bin Salim Aldjufri, Pendiri Alkhairaat (Jakarta: tnp, 1988), h. 4. 
Norma Dg. Siame \& Samsinas Samsinas, Desain Dakwah Sayid Idrus....

\author{
18. Ahmad \\ 19. Muhmamad \\ 20. Ali \\ 21. Muhammad \\ 22. Abubakar Djfar \\ 23. Alwy \\ 24. Abdullah \\ 25. Muhammad \\ 26. Idrus \\ 27. Salim \\ 28. Husain \\ 29. Abdullah \\ 30. Alwy \\ 31. Sagaf \\ 32. Alwy \\ 33. Salim \\ 34. Idrus. ${ }^{3}$
}

Ibundanya bernama Nur yang mempunyai hubungan kekeluargaan dengan Arung Matoa, (raja yang dituakan) di Wajo Sengkang Sulawesi Selatan. Bila di lihat silsilahnya, maka Sayid Idrus memiliki pertautan dua sosok ulama besar (Arab-Bugis), sehingga tidak berlebihan kalau dikatakan memiliki sosok ulama yang mungkin berbeda dengan ulama lainnya. Sayid Idrus adalah putra keempat dari enam bersaudara masing-masing:

${ }^{3}$ Noor Sulaiman, Profil Seorang Ulama Pendiri Alkhairaat ( Laporan Penelitian tidak diterbitkan, 1996), h. 7. 
1. S. Abdul Kadir; wafat di Cianjur-Jawa Barat

2. S. Syekh, wafat di Solo-Jawa Tengah

3. S. Alwi, wafat di Hadramaut

4. S. Idrus, wafat di Palu-Sulawesi Tengah

5. S. Abubakar, wafat di Solo-Jawa Tengah

6. Syarifah Lu'lu wafat di Hadramaut. ${ }^{4}$

Ketika masih tinggal di Hadramaut, Sayid Idrus telah menjalani pernikahan (perkawinan) yang pertama dengan seorang putri bangsawan Hadramaut, namun tidak dikaruniai keturunan karena perkawinannya yang relatif singkat. Kemudian perkawinannya yang kedua, masih dengan wanita Hadramaut, Sayid dan dikaruniai dua orang putra dan satu putri, yakni Sayid Muhammad, Sayid Salim dan Syarifah Ragwan. Sedang perkawinannya yang ketiga setelah berada di Indonesia, Sayid Idrus menikah di Solo dengan Syraifah Aminah dan dikarunia dua orang putri yakni Syarifah Nikmah dan Syarifah Lu'lu. Pada perkawinannya yang keempat setelah berada di Palu, Ia menikah dengan seorang janda bangsawan bernama Intje Ami atau yang biasa disapa dengan sebutan Ite, dikarunia dua orang putri yang diberi nama Syarifah Sa'diyah dan Syarifah Saida.

Sayid Idrus mulai mengenal pendidikan dari lingkungan keluarga melalui ayahanya Sayid Salim Alawy. Sayid Salim Alawy dikenal sebagai seorang ulama besar yang memiliki banyak karya ilmiah dalam berbagai cabang ilmu pengetahuan agama, hukum dan sastra Arab. Sehingga tidaklah mengherankan dalam proses pendidikan yang dijalani Sayid Idrus dalam binaan ayahanya sangat sukses sekaligus memberikan corak,

${ }^{4}$ Ibid., h. 8. 
Norma Dg. Siame \& Samsinas Samsinas, Desain Dakwah Sayid Idrus....

watak dan kepribadiannya. Sayid Idrus sangat tekun, cermat dan disiplin dalam mengatur waktu, juga kegemarannya dalam belajar dan membaca tidak saja di bangku sekolah tapi juga di tempat-tempat seperti serambi mesjid, bahkan di tempat-tempat sepi yang bisa memberikan inspirasi belajar. ${ }^{5}$ Selain belajar dari ayahnya, beliau juga banyak belajar pada ulama besar diantaranya: Sayid Muksin bin Alwy Assaggaf, Sayid Abdurrahman bin Ali bin Umar, Sayid Muhammad bin Ibrahim Bafalgih, Sayid Abdullah bin Husain, Sayid Idrus bin Umar Alhabsyi.

Pada usia remajanya, Sayid Idrus melanjutkan pendidikan keluar daerah yakni di Makkatul Mukarramah selama kurang lebih empat tahun. Oleh karena itu dalam usianya yang masih mudah sudah mampu menghafal dan memahami kurang lebih 200 ayat al-ahkām (landasan hukum-hukum Islam). Kemudian melanjutkan pendidikan ke Perguruan Tinggi dan menyelesaikan studinya di Perguruan Tinggi ArrabitatulAlawiyah di Hadramaut. ${ }^{6}$

Sayid Idrus tidak pernah menulis dalam bentuk buku atau bentuk karya ilmiyah, kecuali sejumlah tulisan dalam bentuk syair-syair yang berbahasa arab. Isi dan maknanya merupakan ajakan, nasihat dan dorongan kepada orang-orang untuk selalu berbuat kebaikan, mencari ilmu pengetahuan, berakhlak mulia, dan sebagainya. Menurut Lahilote, bahwa Sayid Idrus mempunyai karya-karya dalam bentuk syair berbahasa Arab kurang lebih sekitar seribu bait terdiri 48 topik. $^{7}$

${ }^{5}$ Kambay Sofyan, Perguruan Islam dari Masa ke Masa, (Palu: Alhuda 1991), h. 22.

${ }^{6}$ Ibid., h. 23.

'Lahilote Sofyan, Majmu' Qashaid Pendiri Alkhairaat, (Menado: Alkhairaat, 1980), h. 7. 


\section{$\Delta L-$ nish $\exists \bar{\Delta}$ H, Vol. 11 No. 1, Januari-Juni 2015: 21-46}

Ternyata karya-karya tersebut ditulis dalam bahasa Arab, kemudian diterjemahkan oleh Sayid Saggaf Aldjufri (cucu Sayid Idrus) dan menjadi bahan materi pelajaran yang diajarkan di Madrasah Alkhairaat, yang disebut pelajaran ke Alkhairatan setelah ditambah beberapa materi termasuk sejarah berdirinya Alkhairaat yang sekarang ini disebut muatan lokal (mulok) dalam kurikulum pendidikan Alkhairaat. Tujuannya adalah untuk lebih menanamkan rasa kecintaan para siswa terhadap almamater Alkhairaat. Disamping memperkenalkan karya tulis pendiri Alkhairaat, juga menjadi motivasi belajar bagi para siswa-siswi, karena memang isinya mengandung nasihat dan ajakan untuk rajin menuntut ilmu pengetahuan, dan berakhlak mulia. Bait-bait dalam syairnya yang antara lain bernada ajakan untuk menuntut ilmu dan berakhlak mulia, yang sudah di terjemahkan dalam bahasa Indonesia agar mudah difahami oleh murid-muridnya. Sayid Idrus meninggal pada tanggal 22 Desember tahun 1969 Masehi di Kota Palu, Sulawesi Tengah, Indonesia.

\section{B. Desain Dakwah}

\section{Pengertian Dakwah}

Kata dakwah, Secara etimologi, berasal dari bahasa Arab yaitu dari kata; دع- يدعو- دعوة yang berarti "mengajak", "memanggil", "mengundang", "mendorong". Toha Yahya Umar mendefinisikan kata dakwah dengan "Mengajak manusia dengan cara bijaksana kepada jalan yang benar sesuai perintah Tuhan, untuk kemaslahatan dan kebahagian mereka di dunia dan di akhirat'. ${ }^{8}$ Selanjutnya Syekh Ali Mahfuz mendefinisikan, dakwah adalah "Mendorong manusia atas kebaikan dan

${ }^{8}$ Toha Yahya Umar, Ilmu Dakwah, (Cet. IV; Jakarta: Widjaya, 1985), h. 1 
Norma Dg. Siame \& Samsinas Samsinas, Desain Dakwah Sayid Idrus....

mencegah dari kemungkaran guna mendapatkan kebahagiaan hidup di dunia dan di akhirat". "(Dari kondisi) Positif kekondisi yang lebih positif . 9 Sehubungan dengan pengertian ini Rasulullah bersabda:

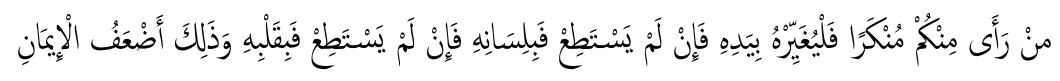

Artinya:

"Siapa di antara kamu melihat kemungkaran, ubahlah dengan tangannya, jika tidak mampu, ubahlah dengan lisannya, jika tidak mampu, ubahlah dengan hatinya, dan yang terakhir inilah selemahlemah iman".H.R. Muslim). ${ }^{10}$

Oleh karena itu Allah telah menyediakan metode yang baik dalam berdakwah sebagaimana difirmankan dalam Alqurān surah an-Nahl (16): 125, berbunyi: "Berdakwahlah kamu dijalan Allah dengan cara hikmah, dan nasehat yang baik dan berdebat dengan cara yang santun..." ${ }^{11}$ Ayat ini memberi indikasi pada dua hal; pertama, perintah dakwah dijalan Allah, atau mengajak umat atau masyarakat baik individu atau kelompok kepada jalan yang dikehendaki Allah atau sesuai ajaran Islam. Kedua, menyangkut cara atau metode berdakwah, bahwa Allah memerintahkan untuk berdakwah atau menegakkan amar ma'rūf nahī munkār di muka bumi dengan cara-cara hikmah, mau'ịah hasanah dan mujādalah yang ahsan.

Dalam kegiatan dakwah tidak terlepas dari beberapa unsur yang disebut dengan unsur dakwah, antara lain; Tujuan dan dasar dakwah

\footnotetext{
${ }^{9}$ Syekh Ali Mahfuz, Hidāyah Murshidīn ilà Turuqi an-Nāṣ wa AlkhaTabah, (Beirut: Dār al-Ma'ārif, tth), h. 1

${ }^{10}$ Muslīm bin al-Hajjāj al-Qushairi, Sahhịh Muslim; Bāb al-Imān, (Cet. 1; Beirut: Dar al-Fikr, 2003), h. 52

${ }^{11}$ Kementerian Agama RI, Alqurān dan Terjemahnya, (Bandung: Fokus Media, 2010), h. 281
} 


\section{$\Delta$ L-nish $\exists \bar{d} / H$, Vol. 11 No. 1, Januari-Juni 2015: 21-46}

(konsep), da'i, mad'u, materi, metode, media, dan feedback (dampak) dakwah. Tujuh unsur inilah yang menjadi wilayah kerja dakwah dan dapat didesain dalam menunjang efektivitas dakwah.

\section{Desain}

Desain biasa diterjemahkan sebagai seni terapan, arsitektur, dan berbagai pencapaian kreatif lainnya. Dalam sebuah kalimat, kata "desain" bisa digunakan, baik sebagai kata benda maupun kata kerja. Sebagai kata kerja, "desain" memiliki arti "proses untuk membuat dan menciptakan obyek baru". Sebagai kata benda, "desain" digunakan untuk menyebut hasil akhir dari sebuah proses kreatif, baik itu berwujud sebuah rencana, proposal, atau berbentuk benda nyata. Proses desain pada umumnya memperhitungkan aspek fungsi, estetika, dan berbagai macam aspek lainnya dengan sumber data yang didapatkan dari riset, pemikiran, brainstorming, maupun dari desain yang sudah ada sebelumnya. ${ }^{12}$

Desain merupakan perencanaan dalam pembuatan sebuah objek, sistem, komponen atau struktur. Kemudian, kata "desain" dapat digunakan sebagai kata benda maupun kata kerja. Dalam artian yang lebih luas, desain merupakan seni terapan dan rekayasa yang berintegrasi dengan teknologi. Desain dikenakan pada bentuk sebuah rencana, dalam hal ini dapat berupa proposal, gambar, model, maupun deskripsi. Jadi dapat dikatan, desain merupakan sebuah konsep tentang sesuatu. Desain lahir dari penerjemahan kepentingan, keperluan, data maupun jawaban atas sebuah masalah dengan metode-metode yang dianggap komprehensif, baik itu riset, brainstorming, pemikiran maupun memodifikasi desain yang sudah ada sebelumnya. Seorang perancang

${ }^{12}$ https://id.wikipedia.org/wiki/Desain, diakses tanggal 28 Mei 2015. 
Norma Dg. Siame \& Samsinas Samsinas, Desain Dakwah Sayid Idrus....

atau orang yang mendesain sesuatu disebut desainer, namun desainer lebih lekat kaitannya dengan profesional yang bekerja dilingkup desain yang bekerja untuk merancang sesuatu yang menggabungkan atau bereksplorasi dalam hal estetika dan teknologi. Lebih spesifik desain merupakan sebuah aktifitas yang bertujuan untuk membangun kualitas multi elemen dalam sebuah objek, proses, layanan dan sistem mereka dalam siklus hidup produk tersebut. Oleh karena itu, desain merupakan faktor utama inovasi manusia dalam teknologi dalam prosesnya berintegrasi dengan budaya, sosial dan ekonomi.

Mendesain merupakan sebuah pola perncangan yang melalui berbagai proses dan pertimbangan estetika, fungsi, masalah, survei dan banyak aspek lain, sehingga seorang yang memilih berprofesi sebagai desainer membutuhkan keahlian, penelitian, pemikiran, model dan pengalaman tertentu dalam orientasinya meng-out-put sebuah karya desain. ${ }^{13}$

Sehubungan dengan defenisi tersebut untuk menemukan nilai struktural, organisasi, fungsi dan ekspresi dengan bidang lain, desain mengemban tugas besar dalam meningkatkan kelestarian global dalam hal lingkungan dan pengolahannya, desain juga dituntut mampu memberikan manfaat dan kebebasan kepada seluruh komunitas manusia baik secara individu, maupun kolektif, desain memiliki implikasi yang cukup luas dalam pembentukan pola berpikir pasar (masyarakat) karena desain menjadi salah satu pendukung keanekaragaman budaya dari berbagai belahan dunia, sehingga desain harus hadir dengan form yang

${ }^{13}$ Sarapanmatahari2010

https://sarapanmatahari.wordpress.com/2010/06/07/pengertian-desain/ diakses tanggal 28 Mei 2015 
mapan saat lahir sebagai sebuah produk baik dalam teori, visual maupun objek dan koheren dengan kompleksitas yang muncul ditengah-tengah masyarakat. desain melibatkan spektrum yang luas dimana berbagai profesi, produk, layanan, grafis, interior, arsitektural dalam berbagai aspek kehidupan. Dengan demikian, desainer muncul sebagai individu maupun komunitas yang bertanggung jawab dalam perkembangan dunia yang multi-dimensional. ${ }^{14}$

\section{Desain Dakwah}

Dakwah sesungguhnya adalah kegiatan memasyarakatkan ajaran Islam dan mengembangkan masyarakat Islam. Oleh karena itu memerlukan keterampilan dan keahlian secara keilmuan dan karakteristik dai menjadi desainer dalam menjalankan kegiatan dakwah dan mengembangkan masyarakat Islam. Demikian pula untuk masyarakat Kota Palu ataupun Sulawesi Tengah.

Dalam rangka desain dakwah tentulah harus created by design oleh da'i atau ulama yang concern dibidang dakwah islamiah yang mengerti tujuan dasar dan unsur-unsur dakwah. Dan dari unsur-unsur tersebut dapat digunakan sebagai basis untuk mendesain kerangka atau pola dakwahnya sehingga nampak atristik dan dinamis dalam seluruh aktifitasnya, memiliki sistem kinerja yang sinergis saling mendukung dan konstruktifitas dakwah islamiah. Kecerdasan dan kelihaian seorang da'i sangat diharapkan dalam menghasilkan desain yang baik dan desain dakwah yang baik akan menghasilkan aktifitas pada tercapainya tujuan dakwah yakni memasyarakatkan ajaran Islam dan mengembangkan masyarakat Islam.

\footnotetext{
14 Ibid.
} 
Norma Dg. Siame \& Samsinas Samsinas, Desain Dakwah Sayid Idrus....

\section{Desain Dakwah Sayid Idrus}

Kemampuan Sayid Idrus dalam melakukan pembinaan dan melakukan perubahan terhadap masyarakat Islam di Sulawesi Tengah. Secara implementatif Sayid adalah pelaku dakwah (da'i) yang memulai debutnya pada tahun 1929 M di tawaili, daerah dekat pelabuhan di Palu Utara yang masa itu termasuk bagian dari Donggala.

Ada beberapa hal yang Sayid lakukan sebagai design dakwah di lembah Palu. Antara lain;

\section{a. Silaturrahim dengan tokoh masyarakat Palu}

Sebagai da'i, ia butuh tempat atau sarana untuk berdakwah, oleh karena itu Ia mulai melakukan silaturrahim ke berbagai kalangan termasuk pemuka adat atau raja-raja dan keluargannya yang berkuasa di Donggala, Parigi, Sigi dan sekitarnya. Hasilnya, beliau mendapatkan tempat mengajar atau berdakwah dirumah seorang saudagar yang bernama H. Quraish di Kampung Ujuna. Secara perlahan tapi pasti ia mulai menerima murid-murid dari masyarakat setempat, dan pendidikan memberi dampak positif bagi kehidupan masyarakat setempat. Pengaruhnya membuat muridnya semakin bertambah, sehingga tidak bisa lagi ditampung dirumah $\mathrm{H}$. Quraysh, lalu dipindahkan lagi ke Kampung Baru dirumah salah seorang tokoh masyarakat bernama Daeng Marotja.

Menyadari banyaknya murid-murid yang ingin belajar kepadanya menyebabkan beliau berputar otak untuk mencari solusi supaya pelayanan tetap berjalan maksimal dan tidak lagi harus menumpang dirumah orang lain.

\section{b. Membangun sarana dakwah}

Pada tahun $1930 \mathrm{M}$, atau kurang dari setahun menjalani dakwah dirumah-rumah, Sayid bersama murid-miridnya resmi membangun 
sarana dakwah berupa sebuah masjid dan bangunan sekolah (madrasah) sederhana sekaligus awal berdirinya Perguruan Alkhairaat. ${ }^{15}$ Perguruan ini pula menjadi lembaga pendidikan formal.

Madrasah dipetakan berdasarkan usia sehingga berdiri Madrasah Ibtida'iyah, Madrasah Tsanawiyah dan Madrasah Aliyah. Dakwah yang Sayid melalui pendidikan ini berkembang pesat sehingga selama 39 tahun mampu mendirikan madrasah sebanyak 420 unit diberbagai daerah di Sulawesi Utara, Sulawesi Tengah, Irian Jaya dan Sulawesi Selatan dan Kalimantan Timur. Bahkan kini telah berdiri pula Perguruan Tinggi (alJami'ah) atau Universitas Alkhairaat (UNISA).

Para sarjana era kemudian mengatakan, Sayid Idrus telah melakukan moderenisasi pendidikan dari pendidikan sistem khalaqah, ceramah dor to dor atau dari khalaqah ke khalaqah menjadi pendidikan dalam sistem kurikuler dan terstruktur dimana semua unsur dakwah atau unsur pendidikan terlibat secara sistemik dan sinergis dan saling mendukung pada pengembangan pendidikan itu sendiri.

Jika memperhatikan masa kedatangan Sayid Idrus di Kota Palu atau Sulawesi Tengah tahun 1930 M dapat diperhitungkan sebagai era modern dimana pola dakwah dan pengembangannya tidak lagi hanya dalam bentuk ceramah, cerita dan hubungan dagang sebagaimana yang

${ }^{15}$ Kata Alkhairaat (الخبرات) berarti "kebaikan". Kata ini diilhami oleh ayat-ayat Alqur'an, diantaranya terdapat pada surah Al-Baqarah ayat 148, Surah ali-Imran ayat 114 , surah al-Maidah ayat 48 , surah at-Taubah ayat 88 , surah al-Anbiya ayat 73 , surah alAnbiya ayat 90, surah al-Mukminun ayat 61 dan surah Fathir ayat 32. Secara spirit psykologis kita bisa memahami bahwa Sayid Idrus menggunakan kata Alkhairaat sebagai suatu harapan akan terwujudnya kebaikan bagi masyarakat dan pengembangan Islam di Kota Palu atau Sulawesi Tengah bahkan di Indonesia pada umumnya. 
Norma Dg. Siame \& Samsinas Samsinas, Desain Dakwah Sayid Idrus....

terjadi pada abad XVII hingga abad XIX. Sebab pada awal abad XX M moderenisasi bermunculan diberbagai belahan dunia terutama dinegaranegara jajahan seperti Mesir, Afganistan, Pakistan, India, Malaysia dan Indonesia. Masa ini, negara-negara kolonial (penjajah) membawa sekaligus memperkenalkan peralatan perang, pertanian, industri, komunikasi, transportasi dan pendidikan yang sangat moderen pada zamannya.

\section{c Sistem rekrutmen mad'u atau murid}

Murid merupakan mad'u yang didakwahi secara paedagogik. Yang dengan demikian Sayid juga adalah seorang guru atau pendidik. Sebagai seorang pendidik, Sayid Idrus membuka sisten perekrutan murid. Pada awal penerimaan murid, dilakukan dengan pertimbangan kapasitas dan kualitas murid karena diharapkan dalam waktu singkat telah dapat membantu mengajar sekaligus punya kemampuan atau kapabilitas untuk berdakwah.

Ada beberapa tekni yang dilakukan dalam perekrutan murid baru sebagai mad'u dalam sistem paedagogik, yakni;

a. Sayid Idrus menerima murid menggunakan ketajaman pandangan dan batinnya. Murid-murid yang diterima pada masa awal itu memang berkualitas, baik dari segi bobot ilmu yang dimilikinya, ketangguhan dalam melaksanakan tugas, keikhlasan dalam pengabdian dan sebagainya. Murid-murid yang pertama dibina dan digembleng jiwanya dan diasah otaknya itu dipacu belajarnya tanpa mengenal waktu istirahat. Sehingga dalam waktu kurang lebih empat tahun lamanya, mulailah diuji kemampuannya baik dalam melaksanakan dakwah maupun sebagai guru. Muridnya yang pertama yang dipilih diantaranya adalah Muhammad Qasim Maragau, seorang anak dari golongan orang tuanya yang kurang 


\section{$\Delta L-$ nish $\exists \bar{\Delta}$ H, Vol. 11 No. 1, Januari-Juni 2015: 21-46}

mampu. Namun dalam pandangan Sayid Idrus bahwa anak tersebut memiliki bakat dan kemampuan serta sifat-sifat dan karakter, yang kelak anak tersebut akan dapat diperhitungkan. Diambilnya Mohammad Qasim Maragau dimasukkan dalam pesantren yang juga rumah kediaman Sayi Idrus bersama beberapa orang temannya, lalu dilakukan pembinaan khusus dengan membina mental dan kepribadiannnya. Diisi dengan berbagai ilmu pengetahuan agama sampai dapat memiliki ilmu yang memadai, bahkan dinyatakan sebagai murid yang pertama paling genius. Dan ternyata memang benar, setelah beberapa tahun kemudian, Muhammad Qasim Maragau ini diangkat oleh Departemen agama menjadi Kepala Kantor Agama Sulawesi Utara Tengah yang waktu itu administrasi pemerintahan masih satu Sulawesi Utara-Tengah. ${ }^{16}$

b. Merekrut murid-murid yang berkualitas. Dalam rangka mempercepat pengembangan Alkhairaat, dilakukan lewat pembentukan group sepak bola. Secara diam-diam dimanfaatkan untuk mencari muridmurid yang berbakat. Dengan pola mengamati karakter dan sifat-sifat dari peserta pemain. Ternyata dengan pola itu mendapatkan beberapa orang anak yang memiliki bakat dan kemampuan untuk dibina di pesantren. Dihubungilah orang tua anak agar dimasukkan dalam pesantren yang dibinanya untuk dididik secara cuma-cuma tanpa memungut biaya. ${ }^{17}$

c. Mencari murid-murid yang berbakat, yakni ketika mengantarkan guru-guru agama ke daerah-daerah sesuai permintaan masyarakat yang berkeinginan untuk membuka madrasah. Sayid Idrus memanfaatkan untuk mencari sekaligus menerima murid yang selanjutnya dibawa ke Palu untuk dibina dan dididik dipesantren Alkhairaat. Cara atau metode

\footnotetext{
${ }^{16}$ K.H.Naawian Abdulllah, Wawancara tanggal 25 Oktober 2008, di Palu ${ }^{17}$ Ibid. 25 Oktober 2008.
} 
Norma Dg. Siame \& Samsinas Samsinas, Desain Dakwah Sayid Idrus....

yang digunakan dalam penerimaan murid tersebut dimaksudkan untuk pengembangan misi Alkhairaat ke depan dan mencetak kader-kader ulama yang handal. Sesuai dengan infomasi bahwa waktu awal kedatangan Sayid Idrus di Palu belum ada ulama atau muballigh khususnya dari suku Kaili. Sehingga dengan pertimbangan itulah selalu diperioritaskan anak yang memiliki bakat dan kemampuan khususnya dari masyarakat setempat (Kaili). Dan selebihnya setelah menamatkan pelajaran dikirim kembali pulang ke daerahnya untuk membuka madrasah Alkhairaat sekaligus mengajar di sana. Itulah sebabnya maka madrasah Alkhairaat dapat berkembang cepat di daerah-daerah khususnya di pedesaan.

\section{d. Sistem Dakwah}

Melalui madrasah, Sayid mengembangakan dakwahnya dengan menggunakan beberapa sistem pengajaran, antara lain;

1) Ceramah keliling. Ceramah ini lebih pada kegiatan dakwah yang bersifat tradisional dimana kegiatan ini dilakukan pada kesempatankesempatan yang terjadwal dan dilakukan diluar madrasah, seperti khutbah jum'at dimasjid-masjid atau sesuai kebutuhan masyarakat yang mengundang untuk mendengarkan dakwahnya. Ceramah ini juga dilakukan pada saat beliau berkunjung diluar daerah Palu ditempattempat persinggahan dalam perjalanannya pun beliau menyempatkan diri untuk memberi pencerahan pada murid-muridnya.

2) Khalaqah (Rokhah). Sistem yang berlaku di madrasah, dimana murid duduk melingkar dan guru (Sayid) berada ditengah. Sistem ini biasa dilakukan didalam madrasah atau sekolah. Pemberian materi pelajaran lebih fokus dan mendalam. 
Sistem Khalaqah ini dibagi menjadi dua tingkatan, yakni : Khalaqah untuk tingkat guru-guru dan khalaqah untuk tingkat santri atau murid, yakni :

a) Khalaqah untuk guru

Sistem ini dilakukan pada sore hari, sedang tempatnya dipusatkan di rumahnya atau di mesjid. Kebiasaan yang dilakukan dimana para guru dianjurkan membawa kitab masing-masing. Dalam sistem ini tidak ditentukan nama kitabnya, namun masing-masing diberi kebebasan membawa kitab sesuai keinginannya. Misalnya kitab fiqhi, kitab tasauf, kitab tafsir, kitab hadist, ushul fiqhi dan sebagainya. Setelah tiba waktunya para guru peserta tersebut sudah berkumpul dan dipersilahkan duduk dan membuka kitab masing-masing dan dipersilahkan membaca secara bergilir sekaligus mengartikan. Bila ada kesalahan dalam membaca atau mengartikan, Sayid Idrus lalu membetulkan dan meluruskan. Begitu juga bila terjadi perbedaan persepsi dan pengertian diantara para murid terhadap suatu ayat atau hadits, maka Sayid Idrus lalu memberikan penjelasan tentang maksud dan pengertian ayat atau hadits tersebut.

b) Halaqah untuk santri

Sistem halaqah rokhah ini dilakukan setelah selesai shalat subuh sampai jam 06.30. Pada sistem ini para santri dianjurkan membawa kitab masing-masing yang sama, kemudian disuruh membaca secara bergilir sedangkan Sayid Idrus sendiri mendengarkan sambil membetulkan yang bacaan-bacaannya salah sekaligus memberikan penjelasan-penjelasan terhadap masalah-masalah yang dianggap penting.

Selain sistem tersebut Sayid Idrus juga tetap memanfaatkan kesempatan untuk membaca bahkan juga mengajar ketika sedang 
Norma Dg. Siame \& Samsinas Samsinas, Desain Dakwah Sayid Idrus....

melakukan perjalanan dalam mengunjungi cabang-cabang madrasah Alkhairaat yang ada di daerah-daearh seperti Menado, Ternate dan Sangir Talaud, yang selalu disertai dengan murid-muridnya. Di setiap tempat persinggahan istirahat menginap, Sayid Idrus tetap memanfaatkan waktu untuk membaca kitab dan mengajrkan muridmuridnya.

\section{Materi Dakwah}

Materi pelajaran sama dengan materi dakwahnya berupa isi kitabkitab klasik yang memuat ilmu fiqhi, kitab tasauf, kitab tafsir, kitab hadist, ushul fiqhi, dan lainnya yang umumnya masih didominasi oleh ilmu agama. Diajarkan pula materi sejarah dan amsal para nabi dan Rasul, perjuangan sahabat serta para aulia yang layak dijadikan teladan dalam memperjuangkan dan mengembangkan agama Allah serta pembentukan aklakul karimah. Selain itu diajarkan juga materi ke-Alkhairaat-an untuk menumbuhkan kecintaan kepada Alkhairat sebagai lembaga atau wadah perjuangan dakwah Islam.

\section{Dakwah melalui moderenisasi pendidikan Islam}

Salah satu strategi dakwah Sayidadalah melakukan moderenisasi lembaga pendidikan Islam. Moderenisasi yang dimaksud adalah;

a. Pengembangan pendidikan

Sebagaimana yang sudah dijelaskan bahwa awal membuka madrasah, masih menggunakan sepetak tokoh kepunyaan H. Quraisy di Kampung Ujuna, kemudian beralih ke rumah kediaman H. Dg. Marotja di Kampung Baru. Karena murid semakin banyak dan tidak lagi dapat menampung rumah tersebut, maka mulailah berusaha membangun sarana pendidikan, sebuah bangunan berukuran $21 \times 7 \mathrm{~m} 2$ di atas tanah 
seluas 30x30 m2 atas biaya sendiri. Tepat tanggal 14 Muharram $1349 \mathrm{H}$. atau hari Rabu tanggal 11 Juni 1930 M, diresmikanlah sebagai "Perguruan Alkhairaat", yang mendapat sambutan cukup meriah dari masyarakat maupun dari para Magau/Madika. ${ }^{18}$ Yang mana bentuk bangunan pendidikan seperti itu belum pernaha ada sebelumnya.

Masyarakat mengusulkan agar gedung Alkhairaat tersebut diperbesar lagi, tapi karena lokasinya kecil, maka atas saran dari para Magau/Madika serta tokoh-tokoh masyarakat agar lokasinya dipindahkan ke tempat yang agak luas, yang tidak jauh dari madrasah yang sudah dibangun awal. Maka pada tahun 1959 berdirilah bangunan madrasah di atas tanah berukuran kurang lebih lima hektar dengan luas bangunan 30x8m2 berlantai dua atas usaha dan jerih payah Sayid Idrus dibantu oleh para Magau/Madika dan tokoh masyarakat (minoritas) bangsa Arab, dan masyarakat setempat.

Selain sarana belajar juga di lokasi tersebut dibangun sarana mesjid dan asrama pelajar serta rumah tinggal Sayid Idrus sendiri, yang juga berfungsi sebagai tempat menerima tamu-tamu yang datang meminta fatwa, atau datang belajar agama. Selain bangunan madrasah, mesjid dan asrama pelajar yang dibangun di Palu tepatnya di Kampung Kamonji, sekarang disebut Kelurahan Kamonji.

Selanjutnya Sayid Idrus juga membangun madrasah Alkhairaat di desa Dolo kurang lebih $15 \mathrm{~km}$. dari kota Palu. Bangunan tersebut juga awalnya sebuah tokoh pemberian dari seorang tokoh masyarakat yakni H. Latopada, yang kemudian dipugar menjadi madrasah yang berlantai

${ }^{18}$ Kadir A. Guruku Guru Tua ( Pahlawan Tanpa Tanda Jasa), Brosur Pidato Khoul tanggal. 12 Syawal 1429 H. h.3 
Norma Dg. Siame \& Samsinas Samsinas, Desain Dakwah Sayid Idrus....

dua. Untuk membina keberagamaan masyarakat Dolo, maka atas inisiatif masyarkat Dolo, Sayid Idrus diberikan rumah tinggal agar bisa menetap minimal pulang pergi sampai beberapa hari antara Palu dan Dolo.

Bagitu juga di desa Kalukubula yang berjarak kurang lebih $10 \mathrm{~km}$. dari kota Palu, namun sekarang karena pemekaran daerah maka Kalukubula ini sudah masuk dalam wilayah kota Palu Selatan. Di tempat ini juga telah dibangun sebuah madrasah yang juga berlantai dua atas bantuan masyarakat Kalukubula dengan model dan bentuknya sama yang ada di Palu dan Dolo sebuah ciri madrasah yang dibangun oleh Sayid. Selain mengusahakan sarana belajar juga dibangun sarana ibadah berupa mesjid yang terdapat di kompleks Alkhairaat Palu seperti yang sudah disebutkan, namun mesjid yang dibangun Sayid Idrus itu telah direnovasi oleh keturunannya.

Mesjid Alkhairaat yang kedua dibangun di desa Kotarindau Kecamatan Dolo. Mesjid ini memiliki jamaah yang cukup banyak dari sekitarnya yang datang dari desa Kotarindau dan desa-desa lain disekitarnya. Setiap malam para pelajar dan anak-anak panti asuhan Putri Alkhairaat menggunakan masjid ini untuk bertadarrus Al-Qur'an, bertepatan di belakang mesjid itu ada panti asuhan Darul Yatimat yang di asuh oleh ibu-ibu Pengurus organisasi Wanita Islam Alkhairaat Kecamatan Dolo. Gedung panti asuhan tersebut adalah merupakan hibah dari seorang ibu $\mathrm{Hj}$. Hasia Latopada.

b. Pengembangan Kurikulum

Pengembangan lainnya adalah perubahan sistem belajar atau kurikulum dalam perguruan yang dipimpinnya, namun tetap keputusan akan perubahan itu harus dipertimbangkan secara matang dan rasional, punya dasar formal yuridis. Mislanya perubahan itu baru dilaksanakan 
pada Muktamar I Alkhairaat, yang waktu itu dirangkaikan dengan Ulang Tahun berdirinya Alkhairaat yang ke 25 tahun 1956. Perubahan sistem belajar tersebut mengingat telah memiliki banyak cabang serta memiliki peserta didik yang sudah bervariasi baik tingkat usia maupun kecerdasannya, sehingga perlu untuk menyesuaikan kebutuhan tersebut dengan meninjau kembali sistem belajar yang telah ada, sebagaimana tertuang dalam Keputusan Muktamar I yang berbunyi:

"Bahwa dewasa ini perkembangan sistem Pendidikan Nasional semakin mengarah pada proses pemenuhan kebutuhan di segala bidang. Alkhairaat yang merupakan asset bangsa dikawasan ini merupakan sumber daya pendidikan sekaligus sebagai narasumber umat, hendaknya mengantisipasi kecenderungan-kecenderungan tersebut dengan sasaran memberikan nilai tambah bagi perkembangan pendidikan dimasa akan datang". ${ }^{19}$

c. Kaderisasi

Dalam proses rekrutmen murid merupakan langkah awal pembentukan kaderisasi. Melihat bakat, karakter dan loyalitas murid menjadi standar pembinaan kader. Sistem kaderisasi yang secara kongkrit dilakukan Sayid Idrus dalam rangka mengemban missi Alkhairaat khususnya dan dakwah Islam dibawah lembaga Alkhairaat.

Sayid Idrus melakukan berbagai perjalanan jauh baik melalui laut maupun darat mengantar murid-muridnya untuk mengenal alam sekaligus menyaksikan kebesaran Khalik Sang Pencipta (Allah swt), melintasi bukit-bukit terjal, mengarungi lautan luas dengan kendaraan seadanya, kadang-kadang harus dengan berjalan kaki, jika memang tidak ada kendaraan atau kebetulan rusak. sekaligus bertujuan menempa sikap dan mental para murid-muridnya agar menjadi kader yang tangguh.

\footnotetext{
${ }^{19}$ Kantor Pengurus Besar Alkhairaat Palu (Hasil Muktamar I di Ampana 1956).
} 
Norma Dg. Siame \& Samsinas Samsinas, Desain Dakwah Sayid Idrus....

Setiap pekerjaan yang dilakukan diajarkannya kepada muridmuridnya agar dilakukan dengan hati yang ikhlas dan niat yang suci. seluruh abnaul-khairaat ditanamkan rasa cinta dan loyal kepada Alkhairaat. Hasilnya seluruh abnaul-khairaat yang pernah memperoleh pendidikan di Alkhairaat merasa berutang budi terhadap Alkhairaat. Itulah yang mendorong para alumninya untuk kembali mengabdi pada Alkhairaat apakah sebagai guru ataupun sebagai pengelola. Apakah di bidang pendidikan atau pun dibidang organisasi Al-Khairaat. Jika mereka berdomisili diluar Kota Palu, semua abnaul-khairaat akan meluangkan waktu berkumpul bersama pada acara-acara tertentu di Alkhairaat terutama pada hari Haul guru tua (Sayid Idrus), dimana Haul menjadi ajang reuni abnaul-khairaat dari berbagai penjuru negeri.

Sejak tahun 1934 sampai tahun 1956, selama kurang lebih 24 tahun, Sayid Idrus berhasil memberikan kontribusi dasar pengetahuan agama dan keterampilan dalam mencetak kader-kader sebanyak 480 orang, tidak saja berprofesi sebagai guru dan muballigh, tetapi berapa jabatan penting yang patut diperhitungkan dalam negeri ini, baik sebagai politisi, birokrat, pengusaha, wartawan dan sebaginya. Hasil kerja mereka selalu maksimal sehingga kerja mereka patut diperhitungkan.

Dalam meningkatkan kualitas kadernya sayid mengirim kaderkadernya ke Kairo, Mesir tahun 1950. Ia mengirim dua orang santrinya, yakni S.Saggaf Aldjufri dan Abd. Hamid. Keduanya menamatkan studinya pada tahun 1957, dengan perestasi yang cukup memuaskan dan keduanya mendapat gelar MA. Berbekal ilmu yang diperolahnya, kaduanya kembali ke Palu dan mengabdikan dirinya di Alkhairaat.

Sayid Saggaf kemudian ditetapkan oleh Sayid Idrus sebagai pewaris Alkhairaat karena dianggap memiliki kemampuan yang cukup 
besar untuk mengembangkan Alkhairaat ke depan. Sementara Abd. Hamid sendiri tidak sempat mengamalkan ilmunya, karena sepulangnya dari Kairo, diperjalanan pulang ke Palu meninggal dunia karena sakit. Pada tahun selanjutnya di kirim lagi dua orang santri yakni Huzaimah T.Yanggo dan Salim Aldjufri yang keduanya juga berhasil dengan baik dan mendapat gelar Doktor. Kini Huzaemah T. Yanggo yang bergelar Prof. Dr. sedang bertugas di UIN Ciputat Jakarta, dengan berbagai tugas dan jabatan penting, di samping tetap menjadi bagian dari Pengurus Besar Alkhairaat. Sementara Dr. Salim Aldjufri juga sebagai Duta Besar luar negeri di Timur Tengah, juga tetap sebagai Pengurus Besar Alkhairaat membidangi urusan-urusan luar negeri. Pengiriman muridmurid yang berperestasi baik ini tetap dilakukan bahkan tidak saja ke Mesir tapi juga ke Malaysia, Brunai Darussalam dan Paksitan.

\section{Penutup}

Sayid Idrus sebagai da'i profesional mampu menciptakan desain dakwah yang cukup sukses dibidang pendidikan. Sayid dan muridmuridnya yang loyal mampu mendirikan madrasah sebanyak 420 buah hanya dalam masa 39 tahun dakwahnya, dan lebih banyak lagi jumlah madrasah yang berdiri seteleh beliau wafat karena semangat dakwah yang ditanamkannya pada murid-muridnya.

Desain Dakwah yang dilakukannya lebih fokus pada moderenisasi pendidikan yang menekankan pada beberapa sistem pendidikan dalam karya desainnya sendiri, antara lain dalam sistem rekrutmen murid, sistem belajar mengajar, materi pelajaran, pengembangan pendidikan, sistem kaderisasi dan pengembangan mutu serta penyebaran peran para kader. 
Norma Dg. Siame \& Samsinas Samsinas, Desain Dakwah Sayid Idrus....

\section{Daftar Pustaka}

As., Mahmud Samsu, Ulama Pembawa Islam di Indonesia dan Sekitarnya Jakarta: Lentera, 1996.

A., Kadir, Guruku Guru Tua (Pahlawan Tanpa Tanda Jasa), Brosur Pidato Khoul tanggal. 12 Syawal $1429 \mathrm{H}$.

Kementerian Agama RI, Alqurān dan Terjemahnya, Bandung: Fokus Media, 2010.

Mahfuz Syekh Ali, Hidāyah Murshidīn ilā Turuqi an-Nāṣ wa AlkhaṬabah, Beirut: Dār al-Ma'ārif, tth.

al-Qushairi, Muslìm bin al-Hajjāj, Șahih Muslim; Bāb al-Imān, Cet. 1; Beirut: Dar al-Fikr, 2003.

Sofyan, Kambay, Perguruan Islam dari Masa ke Masa, Palu: Alhuda 1991.

Sofyan, Lahilote. Majmu' Qashaid Pendiri Alkhairaat, Menado Alkhairaat, 1980.

Sulaeman PL, Noor. Biografi S. Idrus bin Salim Aldjufri, Pendiri Alkhairaat Jakarta: tnp, 1988.

---------, Noor, Profil Seorang Ulama Pendiri Alkhairaat, Laporan Penelitian tidak diterbitkan, 1996.

Umar, Toha Yahya. Ilmu Dakwah, Cet. IV; Jakarta: Widjaya, 1985.

Sarapanmatahari 2010

https://sarapanmatahari.wordpress.com/2010/06/07/pengertian-desain/ diakses tanggal 28 Mei 2015

https://id.wikipedia.org/wiki/Desain, diakses tanggal 28 Mei 2015 